\title{
Kelâm Ekollerinin İnsan Kudretinin Mahalli Tartışmalarına Anatomik ve Fizyolojik Bir Analiz
}

An Anatomic and Physiologic Analysis of the Discussions on the Locus of Human

Power among the Schools of Kalām

\section{Seyithan CAN}

Doç. Dr., Siirt Üniversitesi, İlahiyat Fakültesi, Siirt/Türkiye Associate Professor Dr., Siirt University, Faculty of Theology, Siirt/Türkiye seyithancan@gmail.com | orcid.org/0000-0002-2336-4179 | ror.org/05ptwtz25

\author{
Makale Bilgisi Article Information \\ Makale Türü Article Type \\ Araştırma Makalesi Research Article \\ Geliş Tarihi Date Recieved \\ 14 Temmuz 2021 14 July 2021 \\ Kabul Tarihi Date Accepted \\ 30 Kasim 202130 November 2021 \\ Yayın Tarihi Date Published \\ 31 Aralık 202131 Aralık 2021 \\ Intihal Plagiarism
}

Bu makale, iTenticate yazılımı ile taranmıştır. İntihal This article has been scanned with iTenticate tespit edilmemiştir. software. No plagiarism detected.

Etik Beyan Ethical Statement

Bu çalışmanın hazırlanma sürecinde bilimsel ve etik It is declared that scientific and ethical principles ilkelere uyulduğu ve yararlanılan tüm çalışmaların kaynakçada belirtildiği beyan olunur (Seyithan Can). have been followed while carrying out and writing this study and that all the sources used have been properly cited (Seyithan Can).

CC BY-NC-ND 4.0 lisansı ile lisanslanmıştır. Licensed under CC BY-NC-ND 4.0 license.

Atıf | Cite As

c Can, Seyithan. "Kelâm Ekollerinin İnsan Kudretinin Mahalli Tartışmalarına Anatomik ve Fizyolojik Bir Analiz”. Kader 19/2 (Aralik 2021), 631-644. https://doi.org/10.18317/kaderdergi.971440 


\section{Öz}

Kudret konusu, İslâm kelâmında kader tartışmalarının temelini oluşturan insan fiilleri bağlamında ele alınmış ve tarihsel süreçte birçok yönüyle tartışılmıştır. Bu bağlamda kudretin mahalli de üzerinde durulan önemli konuların başında yer alır. Kudretin mahallinin olup olmadığı, varsa, neresi olduğu ile ilgili tartışmalarda Mu'tezile, Eş'arîlik ve Mâtürîdîlik ekolleri farklı görüşler ortaya koymuşlardır.

Mu'tezile âlimlerinin, kudretin mahalli olduğu ve bu mahallin beden olduğu hususunda ittifak ettikleri görülür. Ancak kudretin mahallinin bedendeki yeri ve cinsi konusunda farklı yaklaşımlar sergilerler. Bazı âlimler, organlarda bulunan kudretin aynı cins olduğunu savunurken bazıları da bu kudretin farklı cins olduğunu düşünmüşlerdir. Eş̧arîlik ve Mâtürîlîlik ekolleri ise kudretin mahallinin olmadığını kabul etmiş ve kudretin fiile etki edeceği esnada Allah tarafından yaratıldı̆̆ını vurgular.

Kelâm ekollerinin bu görüşleri günümüz anatomi biliminden elde edilen bulgular çerçevesinde ele alındığında; Mu'tezile'nin kudretin mahallinin beden olduğu ve tek bir yerden organları etkileyerek fiili meydana getirdiği görüşünün günümüz bilimiyle paralellik arz ettiği görülür. Çünkü kelâm âlimlerinin kudret olarak tanımladıkları mâna, günümüz anatomi bilimi çerçevesinde ele alındığında, kasları harekete geçiren elektriksel aktivite (uyartı) olarak kabul edilmiştir. Bilimsel olarak hareketin meydana gelmesi için ilk önce beyinde oluşan ve motor sinirler aracıllı̆ıyla kaslara iletilen elektriksel aktivitenin olması gerekir. Şayet beyindeki elektriksel aktivite olmazsa insanın hareket sistemini oluşturan, kaslar ve enerji aktif olmayacak böylece hareket gerçekleşmeyecektir.

Mu'tezile âlimlerinden bazılarının kudretin organlarda olduğuna yönelik düşüncelerinin de bilimsel bir karşılık bulmadığ 1 söylenebilir. Kudretin aynı cins mi yoksa farklı cins mi olduğu konusunda yapılan tartışmalarda ise aynı cins olduğunu savunan âlimlerin görüşlerinin isabetli olduğu tespit edilmiştir. Çünkü kudret olarak kabul ettiğimiz elektriksel aktivite, beyindeki oluşum sürecinden sonra organlara yayılır. Dolayısıyla organları harekete geçiren kudretin aynı cins olduğu ortaya çıkmıştır. Ancak Mu'tezilî âlimlerin kudretin mahallinde sürekli bulunduğuna dair ortaya koymuş oldukları görüşün günümüz bilimsel verileriyle uyumluluk arz etmediği görülmüştür.

Eş‘arîlik ve Mâtürîdîlik ekollerinin kudretin sürekli mahalli olmadığına dair ortaya koymuş oldukları görüşlerinin günümüzde beyin aktiviteleri üzerinde yapılan deneylerle uyumlu olduğu tespit edilmiştir. Çünkü insan edimi oluşacağı esnada bu edimi meydana getiren elektriksel aktivitenin fiilden önce ve insanın iradesi dışında beyinde ortaya çıktığı, yapılan bazı deneysel çalışmalarla belirlenmiştir. Eş‘arî ve Mâtürîdî tartışma âlimlerinin kudretin sürekli olarak bedende bulunmadığı ve her defasında Allah tarafından yaratıldığı görüşü elektriksel aktivite olarak tanımladığımız kudretin yaratılışı ile uyumluluk arz ettiği söylenebilir.

Anahtar Kelimeler: Kelâm, Kudret, Kudretin mahalli, Modern bilim, Elektriksel aktivite.

\section{Abstract}

The issue of power has been addressed as part of human actions, which form the basis of the discussions of destiny in Islamic theology. Various schools of kalām have extensively discussed the issue of power throughout history. The locus of power is also one of the critical concerns that have been emphasized within these discussions. The schools of the Mu'tazila, al-Ash'arī and al-Māturīīi have put forward different perspectives on whether the locus of power exists or not and where it exists if it does so.

Mutazilites are known to be in agreement with the view that te human body is the substrate of power. On the other hand, However, they hold different views, not only on the exact locus of power in the body but also on its type. While some argue that the locus of power in the body is the organs, others claim that it is not the organs. The schools of al-Ash'ari and alMāturīin accept that there is no locus for power and emphasize that power is created by Allah the moment it would initiate action.

When these views of the kalām schools are considered within the framework of the data from the modern science of anatomy, it is seen that what modern science has to say on this issue concurs well with the Mu'tazilite view that the locus of power is the body and that it creates the action by managing the organs from a single center. This is because, when considered from the lens of anatomy, what is meant by the schools of kalām with "power" is electrical activity (stimulus) that activates the muscles. Therefore, scientifically considered, for any movement to occur, an electrical activity must first begin in the brain and be transmitted to the muscles via motor nerves. If there were no electrical activity in the brain, 
the muscles and energy that make up the human movement system would not be active, so movement would hardly take locus.

Therefore, the claim made some of the Mu'tazili scholars that the power is in the organs is scientifically not valid. As for the debates on whether the power in different organs is the same or different in terms of its type, the views of the scholars who argue that they are the same genus are apparently correct. This is because the electrical activity, which we accept as power, spreads to the organs after it is formed in the brain. This implies that the power which activates the organs is of the same type. However, it can be said that Mu'tazila's idea of the constant presence of power in its locus conflicts with modern scientific data.

The views of al-Ash'arite and al-Maturidite schools that power is free from being in a constant location are compatible with the findings of recent experiments on brain activities. That is, some experimental studies have indicated that the electrical activity that creates an act occurs in the brain before the act itself and outside the will of the human. In brief, the view of Ash'arite and Maturidite scholars that power is not constantly present in the body and that it is created by Allah each time it is needed is compatible with the creation of power, which we define as electrical activity.

Keywords: Kalām, Power, the Locus of power, Modern science, Electrical activity.

\section{Giriş}

İnsan fiillerinin oluşum süreci kader konusunu doğrudan ilgilendirdiğinden kelâm âlimleri arasında ciddi polemiklere sebebiyet vermiştir. Kelâm tarihinde kader konusu bağlamında yapılan tartışmalara bakıldığında insan fiillerinin bu tartışmalarda belirleyici bir rol üstlendiği söylenebilir. İnsan fiilinin oluşum sürecinde insanın mı yoksa Allah'ın mı kudretinin etkin olduğu hususu birçok kelâmî polemiğin temelini oluşturur.

Müslüman kelâmcılar, insan fiillerini açılamak için hem fizik hem de metafizik kavramları kudretle izah etmeye çalışmışlardır. Fakat onların bu görüşü doğal nesnelerin bilimsel bir açıklaması olmaktan ziyade metafizik bir açıklama olarak kalmışıı. Yani kudret kavramı hiçbir zaman biyoloji veya fizik bilimlerindeki yapısıyla incelenmemiștir. Dolayısıyla kelâm geleneğinin kudret ve kudretin etkinliğine yönelik oluşturdukları teorilerin teolojik bir açıklama olmaktan öteye geçemediği görülür. Konunun kudret olduğu metafizik bir teorinin günümüz açısından geçerliliğinin sağlanabilmesi için ilk etapta biyolojik bir yön ifade eden bu kavramın günümüz biyolojik verileri bağlamında ele alınması gerekir. Çünkü insanın fiil sürecinde etkin olan kudretin biyolojik bir yönü bulunmaktadır. Bu yönü tespit edip belirtmeden bunun üzerinde inşa edilecek her teori riskler barındıracaktır. Hatta kelâmın bilimsellik vasfını kazanması da bu şekilde mümkün hale gelecektir. Şayet kelâm bir bilim olma vasfını yitirirse akâitten ibaret kalacağı aşikârdır. ${ }^{1}$

Dönemlerin fizik teorileri ile metafizik öğretileri arasında doğrudan bir etkileşim söz konusudur. Bir dönemde hâkim olan bilimsel anlayış o dönemin mevcut düşünce dünyasını etkiler. Bu sebeple bir dönemin fizik, matematik, anatomi, fizyoloji vb. bilimlerindeki gelişmeleri dikkate almadan o dönemdeki metafizik düşünceleri anlamak zor olduğu gibi bizzat o dönemde metafiziğin bir bilim olarak inşası da çok zordur. ${ }^{2}$ Âlimlerin kudret üzerinde kurguladıkları teorilerin kendi zamanlarındaki bilimsel verilerle oluştuğu kabul edilse bile günümüzde insan anatomi ve fizyolojisine iliş̧kin bilgiler artmış, gelişmiş ve değişmiştir. Dolayısıyla bu durum biyolojik veya fizyolojik bir yönü bulunan kuramların günümüz bilim verilerine göre değiştirilmesini gerekli

Ömer Türker, Ahlak (İstanbul: Ketebe Yayınları, 2019), 36-37.

Türker, Ahlak, 39. 
kılmaktadır. Her ne kadar günümüz verileri dikkate alınsa dahi gelecekte bilimsel gelişmelerde daha fazla yol katledildiği takdirde bunların da değişebileceği göz önünde her zaman bulundurulmalıdır.

Tarihsel süreçte âlimler, kudret konusunu farklı birçok yönden tartışmışlardır. Kudretin yaratılmışlı̆ıı, fiile etkisi, fiili meydana getirmedeki süreci, fiilden önceliği ve fiille beraberliği gibi tartışmalar kudrete ilişsin oluşturulan temel konulardır. Bu tartışmalarla birlikte kudretin mahalli de ele alınan önemli konuların başında yer alır. Bilimsel verilerin zaman-mekân bağlamında değişebileceği ön kabulünden hareketle çalışmamızda kudretin mahalli tartışmalarının günümüz anatomi ve fizyoloji bilimi açısından değeri ve karşıllı̆ıının tespiti yapılmaya çalışılacaktır.

\section{Klasik Kelâmda Kudretin Mahalli Tartışmaları}

Kelâm âlimleri, fiillerin meydana gelmesi için kudrete ihtiyaç duyulduğu hususunda ortak bir görüş ortaya koyarlar. Bu noktada genel bir ittifak olsa da kudretin bulunduğu yer ve işlevleriyle ilgili aralarında farklı yaklaşımlar görülür. ${ }^{3}$ Kudretin bulunduğu yer ile ilgili tartışmalarda ekoller arasındaki farklılıklarla beraber aynı ekol içerisindeki âlimlerin de farklı bakış açıları ortaya koyduklarını söyleyebiliriz. Bazı âlimler, kudretin mahalli olmadığını belirtirken bazıları da kudretin mahalli olarak insanın bedenini kabul etmişlerdir. Konunun tartışma alanının daha net ortaya çıkması için çalışma içerisinde ele alınacak konuları bir örnek üzerinden açıklamanın yararı olacağı kanaatindeyiz. Örneğin elimizi kaldırdığımızda, bunu yapmamızı sağlayan bir kudrete sahip olduğumuzu anlarız. Çalışmamızdaki tartışma konumuz, elimizi kaldırmamızı sağlayan kudretin yeri neresidir? sorusu etrafında şekillenmektedir. Fiili meydana getiren kudret elimizde mi, bedenimizin başka bir yerinde mi, yoksa dışardan eklenen bir araz mıdır gibi sorulara cevap bulmaya çalışacağız. Ancak bilimsel mukayesenin yapilabilmesi için ilk etapta kelâm ekollerinin yaklaşımını ortaya koymak konunun anlaşılması açısından yarar sağlayacaktır.

\subsection{Kudretin Mahallinin Beden Olduğunu Savunanlar}

Kudretin mahalli olduğunu ve bunun insan bedeni olduğunu söyleyen âlimlerin başında Dırâr b. Amr (öl. 200/815 [?]) gelir. O, kudretin insanın bir parçası olduğunu ve mahallinin insanın bedeni olduğunu belirtir. ${ }^{4}$ Ancak bu görüşü sistematik bir şekilde temellendiren Mu'tezile âlimleridir. Mu'tezile âlimlerinin kudret tanımlarından hareket edildiğinde, kudretin mahalli olarak bedeni kabul ettikleri açık bir şekilde anlaşılır. Mesela Sümâme b. Eşres (öl. 213/828) kudreti, organların sağlam olması ve afetlerden uzak kalması olarak ele alırken, ${ }^{5}$ Bişr b. Mu'temir (öl. 210/825)'in, organların sağlıklı, bünyenin zinde ve belalara karşı dayanıklı olması şeklinde tanımladığı görülür. ${ }^{6}$ Mu'tezile 'den Ebü'l-Kāsım el-Ka'bî (öl. 319/931) kudretin selamet ve sağlık dışında bir

Semih Duğaym, Mevsûatu mustalâhâti'l-Eş'arî ve'l- Kādî Abdülcebbâr (Lübnan: Mektebetu Lubnân, 2002), 534. Abdülkāhir el-Bağdâdî, el-Fark beyne'l-firak, thk. Muhammed Muhyiddîn Abdülhamit (Beyrut: Mektebetü'lUnsuriyye, 1995), 213.

5 Ebü'l-Hasan el-Eş‘arî, Makālâtül'-islâmiyyîn, thk. Helmut Ritter (Beyrut: Dâru'n-Neşr, 2005), 229; Muhammed b. Abdilkerîm bin Ahmed eş-Şehristânî, el-Milel ve'n-nihâl, thk. Emir Ali Menha (Lübnan: Dârü'l-Mârife, 1993), 1/84. Şehristânî, el-Milel ve'n-nihâl, 1/70. 
şey olmadığını ileri sürer. ${ }^{7}$ Kādî Abdülcebbâr (öl. 415/1025) da kudreti, cisimde bulunan mâna olarak ifade etmiş ve bunu insan bedeninde var kılınmış bir potansiyel olarak görmüştür. ${ }^{8}$

Mu'tezile kelâmcilarının kudreti bedende bir mâna olarak telakki etmesi, onu araz kabul etmeleriyle alakalıdır. ${ }^{9}$ Çünkü araz var olabilmek için mekâna ihtiyaç duyar. Kudreti de araz olarak kabul eden Mu'tezile, onun var olabilmesi için mekâna ihtiyaç duyduğunu ve mekânın da insanın bedeni olduğunu vurgular. ${ }^{10}$ Yine onlara göre bir şeyin başka bir şeye gereksinim duyup ve onunla fonksiyonel bir etkileşime girebilmesi, o iki şeyin aynı mahalde ve birbirine yakın olmalarını gerektirir. ${ }^{11}$ Dolayısıyla kudretin fiilini meydana getirebilmesi için bedende bulunmasını zorunlu görmüşlerdir. ${ }^{12}$

Mu'tezilî yaklaşıma göre kudret, insanın ontolojik yapısıyla alakalı bir durum olup insanın varlığı, kudretin de varlığı anlamına gelir. ${ }^{13}$ Öyle ki yatalak bir hastanın, fiil meydana getirememesi kudretinin yokluğundan kaynaklanır. Sağlıklı bir insanın da fiili gerçekleştirebilmesi, organ ve vücut sıhhatinden dolayı sahip olduğu kudret ile alakalıdır. ${ }^{14} \mathrm{Her}$ ne kadar genel olarak Mu'tezile âlimleri kudreti insanın bir parçası olarak kabul etse de Ebü'l-Hüzeyl el-Allâf (öl. 235/849-50 [?]), Muammer b. Abbâd (öl. 215/830) ve Ebû Mûsâ el-Murdâr (öl. 226/841), kudretin araz olarak sağlık ve sağlamlıktan başka bir şey olduğunu belirtir. ${ }^{15}$

Mu'tezilî âlimler, kudretin bedende olduğunu kabul etseler de kudretin bedendeki yeri ile alakalı farklı düşünceler ortaya koyar. Bazıları insanın fiillerini meydana getiren kudretin, insanın bir organı ile değil tüm bedeni ile ilgili bir nitelik olduğunu ve bedenin bir yerinde bulunduğunu söyler. ${ }^{16}$ Meselâ dil ile konuşmayı meydana getiren kudret ile yürümeyi meydana getiren kudret aynı yerdedir. ${ }^{17}$ Dolayısıyla fiilleri meydana getiren kudretin mahalli bir olup, bu kudret ayrı ayrı organlarda bulunmaz. İnsanın meydana getirdiği tüm fiiller, bedende bulunan bu ortak kudretten sadır olur. Bu görüşün önemli savunucularından biri olan Kādîye göre kudret, belirli bir organla değil; insanın bedensel bütünlüğü ile ilgili bir yetkinliktir. Kudret, bedenin bir yerinde bulunur ve bu yerden organı harekete geçirerek fiili meydana getirir. Eylem için gereken kudretin ayrı ayrı organlarımızda olduğunu söylemenin mümkün olmadığını belirtir. Yani ellerimizi kaldırma kudreti elimizde bulunmaz. $O$ bedenin başka bir yerinde bulunur, fiil meydana geldiğinde oradan eli harekete geçirir. Kādî’ye göre her bir organa ayrı ayrı kudret nispet etmek onları ayrı ayrı ama

Bağdâdî, el-Fark beyne'l-firak, 181.

Kādî Abdülcebbâr, Kitâbü'l-mecmu' fi'l-muhit bi't-teklif (Beyrut: Mektebetu'l-Kasulikiyyetu, 1962), 1/216; Kādî Abdülcebbâr, el-Muhtasâr fì usûli'd-dîn, çev. Hulusi Arslan (ìstanbul: Endülüs Yayınları, 2017), 94-95; Kādî Abdülcebbâr, el-Muğnî fi ebvâbi't-tevhîd ve'l-adl, thk. Tavil Tevfik - Zeyd Siad (Kahire: el-Müessesetü'l-Misriyyetü'lAmme, ts.), 6/1/87.

9 Ebü'l-Hasan el-Eş'arî, el-Lüma' fi'r-red 'alâ ehli'z-zeyg ve'l-bida', nşr. Richard J. McCarthy, thk. Ğurabe Hammude (Beyrut: Matbaatu'l-Mısrıyyetu, 1955), 93; Seyyid Şerîf Cürcânî, Şerhu'l-Mevâklf, çev. Ömer Türker (İstanbul: Türkiye Yazma Eserler Kurumu Başkanlığı, 2015), 2/18.

$10 \quad$ Kādî Abdülcebbâr, el-Muhtasâr fi usûli'd-dîn, 94.

11 İbrahim Aslan, Aklın ve Dilin Sinırlarında Kur'ân (Ankara: Ankara Okulu Yayınları, 2016), 79-80.

12 Seyithan Can, İnsan Özgürlüğü ve Sorumluluğu Bağlamında Kudret-Fiil ìlişkisi (Ankara: Araştırma Yayınları, 2019), 67-68.

13 Hasan Ocak, Tanrı-İnsan İlişkisi Bağlamında İnsanın Hürriyeti (İstanbul: Ek Kitap, 2012), 156.

14 Abdunnasır Süt, Mu’tezile ve Ahlak-Kadı Abdulcebbar Örneği (İstanbul: İz Yayıncılık, 2016), 96.

15 Eş‘arî, Makālâtü'l-islâmiyyîn, 229; Şehristânî, el-Milel ve'n-nihâl, 1/84.

16 Eş‘arî, Makālâtü'l-islâmiyyîn, 280.

17 Kādî Abdülcebbâr, el-Muhtasâr fî usûli'd-dîn, 94-95. 
iç içe geçmiş canlı varlıklar olarak kabul etmek anlamına gelir. Bu da her bir organın fiili için farklı yönlendirici nedenleri kabul etmek demektir. Hatta ona göre kudreti, ayrı ayrı organlarda kabul etmek, eyleme yönlendirici nedenler ile eylemden sakındırıcı nedenlerin aynı anda etkili olmasını gerektirecektir. ${ }^{18}$

İkinci görüşe göre her uzvun kudretinin bedendeki mahalli farklıdır. ${ }^{19}$ Yürüme kudreti ayakta, irade kudreti kalpte ve görme kudreti gözdedir. ${ }^{20}$ Ancak insan fiillerini meydana getiren kudretin farklı yerlerde bulunduğunu söyleyen âlimler, kudretin aynı cinsten olup olmadığı konusunda ihtilâf etmişlerdir. Bazıları yürüme kudretinin irade etme kudretiyle aynı cins olduğunu söylerken bazıları da bu kudretlerin farklı cinslerden olması gerektiğini vurgular. ${ }^{21}$

Kudretin organların selameti ve sağlamlığı dışında başka bir şey olduğunu kabul eden Mu'tezilî âlimler, fiilin meydana gelmesi için organda bir engelin bulunmaması gerektiğine dikkat çeker. Şayet organda herhangi bir engel bulunursa o takdirde fiil de meydana gelmez. Örneğin gözün kapalı olması durumunda şayet gözde kudret bulunsa bile gözde görme eylemi gerçekleşemez. Ayrıca elleri ve ayakları bağlanan bir kimse kendisinde hareket kudreti olduğu halde bu kudreti kullanamaz. $^{22}$

Mu'tezilî âlimlerin geneli kudretin mahalli olduğu hususunda aynı görüşü paylaşsalar da Nazzâm (öl. 231/845)'ın genelin aksine farklı bir yaklaşım içerisinde olduğu görülür. O, bizzat insanın kendisinin hayat ve kudret sahibi olduğunu belirtse de insanın, ruh ve bedenden oluştuğunu, bedenin de ruhun aleti ve sûreti olması hasebiyle kudretin ruha ait bir nitelik olduğunu ifade eder. Bu düşünceleriyle Nazzâm, insanın kudretinin ruhta bulunduğunu, ruhun muktedir olduğunu ve insanın fiili işleme yeteneğinde bir engel oluşuncaya kadar fiilin bu ruhla oluştuğunu belirtir. ${ }^{23}$ Nazzâm, Mu'tezilî âlimlerin aksine farklı bir görüş içerisinde olsa da konumuz açısından ele alındığında onun da kudretin bir mahallinin olduğunu kabul ettiği söylenebilir.

Netice itibarıyla Mu'tezile, kudreti araz olarak kabul ettiğinden var olması için bir mahalde bulunmasının zorunlu olduğunu vurgular. Araz temellendirmesi üzerinde kurgulanan bu anlayışta mahal de insanın bedeni olarak kabul edilmiştir.

\subsection{Kudretin Mahallinin Olmadığını Savunanlar}

İnsan kudretinin mahalli olmadığını savunanlar, Eşsarîlik ve Mâtürîdîlik ekolleridir. Her iki ekolun âlimleri, fiili meydana getiren kudreti insandan ayrı bir mâna olarak telakki ettikleri için mahallinin olmadığını kabul eder. Eş'arî, kudretin meydana gelen fillle ilişkisinin olduğunu kabul etse de onu insanın zâtında olması gereken bir vasıf olarak kabul etmez. Ona göre kudret, dışarıdan eklenen bir araz olup bunun kaynağı da Allah'tır. Çünkü insan, kimi zaman bilgili, kimi

18 Kādî Abdülcebbâr, Şerhu'l-Usûli'l-hamse, thk. Abdülkerîm Osman (Kâhire: Mektebetü Vehbe, 1996), 153.

19 Eş'arî, Makälâtül'-islâmiyyîn, 214.

20 Eş‘arî, Makâlâtü'l-islâmiyyîn, 237.

21 Yunus Cengiz, Mu'tezile'de Eylem Teorisi:-Kādî Abdülcebbâr Örneği-, ed. Enes Durmaz (İstanbul: Düşün Yayıncılık, 2012), 128-129.

22 A.S. Tritton, İslâm kelâmı, çev. Mehmet Dağ (Ankara: Anakara Üniversitesi Basımevi, 1993), 122.

23 Hüseyin Vadi, İlmu'l-kelâm ve'l-felsefe, (Mısır: Mektebetü'l-İskenderiyye 1995), 53; Eş‘arî, Makālâtü'l-islâmiyyîn, 229; Şehristânî, el-Milel ve'n-nihal, 1:69; Bağdâdî, el-Fark beyne'l-firak, 135; S. Horovitz, Yunan Felsefesinin Kelâma Etkisi, çev. Özcan Taşçı (ìstanbul: Litera Yayınları, 2014), 26. 
zaman bilgisiz ya da bir zaman hareketli bir zaman da hareketsiz bulunabilmektedir. Ayrıca bazen bir fiile güç yetirebiliyorken bazen de aynı fiili gerçekleştirmekten âcizdir. Eş'arî insanda yaşanan bu durumlardan hareketle insanın zâtı dışındaki bir mâna ile bilgili veya hareketli olduğunu, aynı şekilde zâtı dışındaki bir mâna ile fiile güç yetirebildiğini belirtir. ${ }^{24}$ Ona göre insan zâtından dolayı ya da kendisinde bulunan bir nitelik sayesinde fiili yapıyor olsaydı, bu niteliğin onda süreklilik taşıması gerekirdi ki böyle bir durum kudret için söz konusu değildir. Dolayısıyla insanın aynı fiile bir kez güç getirip başka bir kez güç yetirememesi kudretin onun zâtından ayrı bir varlığa sahip bulunduğunu açıkça ortaya koyar. ${ }^{25}$

Eş‘arî’nin kudretle ile ilgili bu yaklaşımı, ekolün genel anlayışını şekillendirmiştir. Meselâ Abdülkāhir el-Bağdâdî (öl. 429/1037-38), Ehl-i Sünnet'in arazın kendi başına var olamayacağı görüşünden hareketle bir yerde yaratıldığı hususunda ittifak ettiklerini belirtir. ${ }^{26}$ İbn Fûrek (öl. 406/1015) kudreti, insanın dışında bir şey olarak kabul eder. ${ }^{27}$ Ekolün önemli isimlerinden biri olan Bâkıllânî (öl. 403/1013)'nin konuyla ilgili yaklaşımı dikkat çekicidir. O, eğer cisim, kendisinde bulunan bir mâna ile hareketli olursa durması; yine kendisinde bulunan bir mânadan dolay1 durma özelliğine sahip olursa hareket etmesinin uygun olmayacağını ifade eder. Bundan dolayı cismin durmasını ve hareket etmesini sağlayan etkenin insanın zâtının dışında bulunan bir mâna ile olması gerektiğini vurgular. ${ }^{28}$ Eş 'ar̂iliğin kudretin mahalli ile ilgili bu yaklaşımının, ekolünün önemli isimlerinden biri olan Ebu'l-Meâlî el-Cüveynî (öl. 478/1085)'yle de desteklendiğini görüyoruz. Cüveynî, akıllı bir insanın kudretinin varlığının kendisiyle ilgisi olmadığını kesin olarak bildiğini söyler. ${ }^{29}$

Eş‘arîlik ekolünde kudretin bir mahalde bulunmamasının sebebi, iki zıttın bir arada bulunmasının imkânsızlı̆̆ıdır. Onlar, bir şeyin aynı anda hem sakin hem de hareketli olmasının mümkün olmayacağı ön kabulünden yola çıkarak, hareket ile sükûn kudretlerinin bir arada bulunmasının imkânsız olduğunu söyler. Çünkü böyle bir şey olduğu takdirde, iki farklı kudretin ve iki zıt arazın bir mahalde bulunması zorunlu olacaktır. ${ }^{30}$ Bununla beraber Eş'arîler, kudretin sadece bir fiile etki ettiğini kabul eder. Yani bir insanın aynı anda hem bilgili hem de bilgisiz olması demek iki farklı kudret arazının bunlara etki etmesi demektir.

Eş'arîler, kudretin arazlığından dolayı onun sürekli olmadığını belirtir. Sürekli olmadığı için de bir mahalde bulunmasını mümkün görmez. Onlara göre insanın fiili ile kudretin eyleme etki etmesi aynı anda gerçekleşir. Yani insanda kudretin olması, fiilin gerçekleşmesi anlamına gelir. Bu temellendirmelerden hareketle, 'kudret insanda hal'dir diyen veya onun insanda sürekli var olan bir mâna'dır' diyenin görüşlerinin reddedilmesi gerektiğini ifade ederler. ${ }^{31}$ Ayrıca arazların

24 Can, İnsan Özgürlüğü ve Sorumluluğu Bağlamında Kudret-Fiil İlişkisi, 70.

25 Eş'arî, el-Lüma' fi'r-red 'alâ ehli'z-zeyǵ ve'l-bida', 93.

26 Bağdâdî, el-Fark beyne'l-firak, 329.

27 Muhammed b.Hasen İbn Fûrek, Mücerredü makālati'ş-Şeyh Ebi'l Hasan el-Eş'arî, thk. Daniel Gimaret (Beyrut: Dâru'lMeşrik, 1987), 107-108.

28 Muhammed Ramazan Abdullah, Bâkillânî ve ârauhu'l-kelâmiyye (Bağdat: Matbaatü'l-Eimme, 1986), 340; Abdülkāhir elBağdâdî, Usûlü'd-dîn (İstanbul: Dârülfünun İlâhiyat Fakültesi, 1928), 56.

29 Ebü'l-Meâlî el-Cüveynî, eş-Şâmil fị usuli'd-dîn, thk. Ali Sami-en Neşşâr (İskenderiye: Müessestu'l-Meârif, 1969), 182.

30 Ebü'l- Meâlî el-Cüveynî, Kitâbü'l-İrşâd, thk. Muhammed Yusuf Musa - Ali Abdulmunim Abdulhamid (Kahire: Mektebetü'l-Hanci, 1950), 20; İbn Fûrek, Mücerredü makälati'ş-Şeyh Ebi'l Hasan el-Eş'arî, 110.

31 İbn Fûrek, Mücerredü makālati'ş-Şeyh Ebi'l Hasan el-Eş'arî, 108. 
geçiciliğinden hareketle kudretin sürekli olmasının mümkün olmadığını iddia etmiş ve sürekli Allah tarafından yeniden yaratıldığını kabul etmişlerdir.

Eş‘arî, fiili meydana getiren uzuvları dikkate almaması ve kudreti bedenden ayrı bir mâna olarak görmesinden dolayı Mu'tezile tarafından eleştirilmiştir. Onlara göre organın yokluğu, kudretin yokluğunu; kudretin yokluğu da kesbin yokluğu anlamına gelir. Organ yok olduğunda kudret de ortadan kalkar ve kesb imkânsızlaşır. Ancak Eşarî, kudretin organdan farklı bir şey olduğunu vurgulayarak, organın yokluğunun kudretin yokluğu anlamına gelmeyeceğini belirtir. Ayrıca sırf gerekli organ var olmadığı için fiilin kesbî imkânsız hale gelseydi, organ mevcut olduğunda kesbîn mutlaka gerçekleşmesi gerekirdi. Dolayısıyla kesbin kendisi için gerekli organın yokluğu sebebiyle değil, kudretin bulunmayışı sebebiyle meydana gelmediğini ifade eder. ${ }^{32}$

Ebû Mansûr el-Mâtürîdî (öl. 333/944) de Eş'arîler gibi kudreti, cismin cüzlerinden biri olarak görmez. Çünkü ona göre kudret, araz olup bedenin dışında bulunur. ${ }^{33} \mathrm{O}$, kudretin araz olduğunu, sürekliliğini sağlamayacağını, bekâsını başka bir varlıkla sürdürmesi gerektiğini belirtir. Bundan dolayı kudretin hiçbir yerde bulunmadan fiil anında Allah tarafından yaratıldığını vurgular. ${ }^{34}$ Mâtürîdî ekolünün önemli isimlerinden biri olan Ebü'l-Muîn en-Nesefî (öl. 508/1115), arazın cismin dışında bir mâna olması gerektiğini söyler. İnsanların farklı zamanlarda farklı şeylere güçlerinin yetmesini de kudretin organlarla alakalı bir şey olmadığının delili olarak ele alır. 0 , Mu'tezile 'nin kudreti hem araz kabul etmesi hem de onu bedenin parçası olarak görmesinin çelişkili olduğunu iddia eder..$^{35}$ Örneğin, organları sağlam, 50 ratl/litre taşımaya gücü yeten bir adamın daha sonra bir başka durumda vücut azalarının hiçbirinde herhangi bir artma olmamasına rağmen 100 ratl/litre taşıyabilmesinin mümkün olduğunu vurgular. Eğer Mu'tezile 'nin düşündüğü gibi kudret, organlarla ilgili olsaydı bu kişinin taşıyacağ 1 şeyin de değişmemesi gerekirdi. Ancak böyle bir durum söz konusu olmadığı için kudretin cismin bir parçası olduğunu kabul etmek imkânsızdır. ${ }^{36}$

Kudretin mahallinin olmadığını savunan Mâtürîdîlik ekolü de temellendirmelerini Eşsarîler'in yapmış olduğu gibi kudretin arazlığı üzerinden şekillendirir. Eş‘arîler gibi Mâtürîdîler de kudretin araz olduğunu ve devamlı olmadığını söyler. Devamlı olmayan şeyin de sürekliliğini kendisi sağlayamaz. Şayet Mu'tezile gibi arazın sürekli olduğu kabul edilirse bu devamlılığı sağlayan başka bir bekâ arazına ihtiyaç söz konusu olur. Ancak her ikisi de araz olduklarından hiçbir durumda

32 Eş‘arî, el-Lüma' fi'r-red 'alâ ehli'z-zeyg் ve'l-bida', 97.

33 Ebû Mansûr Mâtürîdî, Kitâbu't-Tevhîd, thk. Bekir Topaloğlu - Muhammed Aruçi (Ankara: İSAM Yayınları, 2003$), 346$.

34 M. Saim Yeprem, Matüridi'nin Akide Risalesi ve Şerhi (İstanbul: Marmara Üniversitesi İlahiyat Fakültesi Vakfı Yayınları, 2000), 29.

35 Ebü'l-Muîn en-Nesefî, et-Temhîd fi usûli'd-dîn, thk. Kâbil Abdülhey (Kahire: Dâru's-Sekâfeti Li'n-Neşr ve't-Tevzi', 1987), 55-56; Ebü'l-Muîn en-Nesefî, Tebsiratü'l-edille fî usûli'd-dîn, thk. Muhammed Enver Hamid İsa (Kahire: elMektebetü'l-Ezheriyye li't-Türâs, 2011), 2/783-784; Ebü'l-Muîn en-Nesefî, Kitâbu't-Temhîd li kavâidi't-tevhîd, thk. Hasan Ahmed Cibullah (Kahire: Dâru't-tabâati'l-Muhammediyye, 1986), 260-261.

36 Nesefî, et-Temhîd fî usûli'd-dîn, 55-56; Nesefî, Tebstratü'l-edille fî usûli'd-dîn, 2/783-784. 
beraber bâkî olmaları mümkün değildir. ${ }^{37} \mathrm{Bu}$ temellendirmelerden hareketle Mâtürîdî geleneği kudretin her defasında yeniden yaratıldı̆̆ını söyler. ${ }^{38}$

Netice itibarıyla kelâm geleneğinin en güçlü kanadı olan Ehl-i Sünnet, nesnelerin bütün hareketini ve konumunu doğrudan ilâhî kudrete dayandırır. Kudretin araz olmasından dolayı herhangi bir mahalde sürekli olarak bulunmasının mümkün olmadığını kabul etmiştir.

\section{Modern Bilim Bağlamında Kudretin Mahalli}

Kelâm ekollerinin kudretin mahalli kapsamında ortaya koymuş oldukları görüşlerin modern anatomi ve fizyoloji bilimleri çerçevesinde ele alınabilmesi için kudretin bilimsel olarak mahallinin olup olmadığı; varsa bedenin neresinde olduğunun tespit edilmesi gerekir. Kelâm âlimlerinin kudret tanımları farklılaşsa da her âlimin fiili meydana getiren kudreti, uzuvlardan farklı olarak ele aldığını belirtmek gerekir.

Kudretin mahallinin bilimsel olarak tespit edilebilmesi için ilk etapta kudretin insanın biyolojik yapısında neye tekabül ettiğini ortaya koymak gerekir. İnsanın hareket sistemi çerçevesinde ele alındığında, insanda hareketin olması için iskelet sistemi, kaslar, sinir sistemi ve enerjinin olması zorunludur. ${ }^{39}$ Her ne kadar bu yapılar fiilin meydana gelmesi için gerekli olsa da bunların varlığı da fiilin olması anlamına gelmez. Esasında bunların işlevsel bir hal almaları beyinde oluşan elektriksel aktiviteyle gerçekleşir. ${ }^{40}$ İnsan hareket etmek istediğinde beyninde elektrik sinyalleri ortaya çıkar. Bu sinyaller, motor bölgedeki nöronlar aracilığılla kaslara sinyaller gönderir. Kaslara gelen sinyallerden sonra kasın kasılması için enerji oluşmaya başlar ve bu enerjiyle insanın kası kasılarak bağlı olduğu iskelet sistemini harekete geçirir. Dolayısıyla kelâm âlimlerinin kudret olarak tanımladıkları mâna, modern anatomi ve fizyoloji bilimi çerçevesinde ele alındığında, kasları harekete geçiren elektriksel aktivite (uyartı) olarak kabul edilebilir. ${ }^{41}$ Her ne kadar hareket için iskelet sistemi, kaslar ve sinir sistemi zorunlu olsa da modern anatomi ve fizyoloji bilimleri ışığında ele alındığında bu yapıların varlı̆̆ı, hareketin olması için yeterli değildir. Bunların işlevselliği, beyinde oluşan elektriksel aktivite ile sağlanır. Bu bağlamda kelam âlimlerinin insanın kudreti olarak kabul ettikleri; “uzuvları harekete geçiren mâna'nın beyinde oluşan elektriksel aktivite olduğu söylenebilir. Yani hareketin meydana gelmesi için ilk önce beyinde oluşan ve motor sinirler aracılığıyla kaslara iletilen elektriksel aktivitenin olması gerekir. Şayet beyindeki elektriksel aktivite olmasa insanın hareket sistemini oluşturan kaslar ve enerji aktif olmayacak, böylece hareket gerçekleşmeyecektir. İnsan kudretinin elektriksel aktivite olarak kabul edilmesinden sonra bunun insanın beyninde oluşan bir kuvve olduğu da ortaya çıkar. ${ }^{42}$ Dolayısıyla insan kudretin mahallinin beyin olduğu düşünülebilir.

37 Ebü'l-Yüsr Pezdevî, Ehl-i Sünnet Akaidi, çev. Şerafettin Gölcük (İstanbul: Kayıhan Yayınları, 2015), 173.

38 Seyithan Can, “İnsan Özgürlüğü Bağlaminda Kudretin Devamliliği Sorunu”, İnönü University International Journal of Social Sciences (INIJOSS) 7/2 (2018), 13-14.

39 Jane B. Reece vd., Campbell Biyololoji, çev. Ertunç Gündüz, İsmail Türkan (Ankara: Palme Yayınc1lık, 2013), 858 vd.

40 Arthur C. Guyton - John E. Hall, Tıbbi fizyoloji, çev. Hayrunnisa Çavuşoğlu (İstanbul: Nobel Yayınları, 1996), 85 vd.

41 Seyithan Can, "Modern Anatominin Hareket Kuramı Ekseninde Klasik Kelâmın İnsan Fiilleri Anlayışına Uzlaşımcı Yaklaşım", Kader 18/2 (2020), 582.

42 Can, "Modern Anatomi", 582-583. 
Kudretin mahallinin beyin olduğu tespiti üzerinden konuyla ilgili olarak kelâm âlimlerinin görüşlerini mukayeseli bir şekilde değerlendirebiliriz. Mu'tezile ekolü açısından ele alındığında Mu'tezile'den bazı âlimlerin kudreti uzuvlarda bulunan mâna olarak kabul etmeleri, günümüz anatomi ve fizyoloji bilimi açısından uygun görünmemektedir. Tartışmaların anatomik açıdan analizine bakıldığında kudretin organa bağlı bir şey olmadığı, insanın tüm bedeniyle ilintili bir nitelik olduğu ve bedenin bir yerinde bulunduğu ortaya çıar. Mesela fizyolojik verilere göre dil ile konuşmayı meydana getiren kudret ile yürümeyi meydana getiren kudret aynı yerdedir. Dilde konuşma gerçekleşeceği zaman beyinde ortaya çıan kudret (Elektriksel aktivite) insanın konuşmayı yapan kaslarına iletilmekte ve dilin hareketini sağlamaktadır. Aynı şekilde bir kişi yürümek istediğinde beyindeki elektriksel aktivite (kudret) ayak kaslarına motor sinirler aracilı̆̆ıyla kaslara iletilir ve kaslardaki tepkimelerden sonra yürüme eylemi gerçekleşir. Anatomik ve fizyolojik yaklaşım çerçevesinde ele alındığında, kudretin mahalli ve etki etme süreciyle alakalı Mu'tezile 'nin önemli âlimlerinden Kādînin görüşlerinin kayda değer olduğu görülür. Anatomi ve fizyoloji bilimi ile mukayesesini onun vermiş olduğu örnek üzerinden ele almak konunun daha iyi anlaşılmasında katkı sağlayacaktır. Kādîye göre kudret, bedenin bir yerinde bulunur ve bu yerden organı harekete geçirerek fiili meydana getirir. Dolayısıyla eylem için gereken kudretin ayrı ayrı organlarımızda bulunduğunu söylemenin mümkün olmadığını ifade eder. Yani ellerimizi kaldırma kudreti elimizde bulunmaz. $\mathrm{O}$, bedenin başka bir yerinde bulunur. Fiil meydana geldiğinde oradan eli harekete geçirir. ${ }^{43}$ Kādî̀nin kudretin yeri ve organlara etkisi konusunda ortaya koymuş olduğu düşünce günümüz anatomi biliminin verileriyle uyumlu görünmektedir.

Mu'tezilî âlimlerin kudret ile alakalı tartıştıkları diğer konu da kudretin cinsi meselesidir. Ekol içerisinde ortaya konan farklı yaklaşımlar göz önünde bulundurulduğunda, kudretin "elektriksel aktivite" olarak uzuvların tamamına etki ettiğini söyleyebiliriz. Dolayısıyla uzuvların tamamını etkileyen kudretin aynı cins olduğunu savunan âlimlerin görüşlerinin günümüz fizyoloji bilimiyle uyumluluk arz ettiği görülür. Her uzuvda farklı bir kudret türünün olduğunu söyleyen âlimlerin bu görüşlerinin ise günümüz açısından bilimsel bir karşıllı̆̆ının olmadığı ortaya çıkmıştır.

Mu'tezile âlimlerinin kudretin mahalli ve etki alanı için ortaya koydukları görüşler, günümüz bilimiyle uyumlu görünse de kudretin mahallinden kastın kudretin sürekli olarak bulunduğu yer anlamında kullanıldığının altını çizmek gerekir. Tartışmayı bu bağlamda ele aldığımızda, kudret olarak tanımladığımız elektriksel aktivite beyinde oluşsa da bu aktivitenin beyinde sürekli bulunduğunu söylemek zordur. Çünkü her ne kadar tartışlan bir yönü olsa da Benjamin Libet'in yapmış olduğu deneyde fiilin ateşlenmesi için beyinde hazır bir elektriksel aktivite olmadığı fiili meydana getiren aktivitenin fiilden önce beyinde meydana geldiği belirtilir. Bu deneyden farklı olarak Haynes ve arkadaşları tarafından da yapılan Libet deneyine benzer bir deneyde bireyler hareketlerini yapmadan önce elektriksel aktivitenin beyinde yeni çıtı̆̆ı gözlemlenmiştir. Yani fiilden önce beyinde sürekli fiil için bir aktivitenin olmadığı ölçülmüştür. Her ne kadar bu deneyler insanın özgürlüğ̈̈ ve fiillerinde sorumluluğu bağlamında tartışılsa da konumuzu ilgilendiren yönü fiili meydana getiren elektriksel aktivitenin beyinde sürekli olmadığını ortaya

43 Kādî Abdülcebbâr, Şerhu'l-Usûli'l-hamse, 153. 
koymalarıdır.44 Bilginin değişebilirliği göz önünde bulundurularak bunlardan hareket edildiğinde, kudretin sürekli olarak bir bedende veya bir mahalde bulunduğu görüşünün günümüz biliminde bir karşılık bulmadığını söyleyebiliriz.

Eş‘arîlik ve Mâtürîdîliğe bakıldığında onların insan fiillerini meydana getiren kudretin mahallinin olmadığını savunduklarını yukarıda da ifade etmiştik. Onlara göre kudret, insanın herhangi bir uzvunda bulunmadığı gibi bedeninde de bulunmaz. Bu iki ekole göre kudret, fiil meydana geldiği esnada Allah tarafından yaratılır. Bu iki ekolün benimsemiş olduğu görüş, modern anatomi ve fizyoloji bilimde kısmen de olsa bir karşılık bulmuştur. Çünkü elektriksel aktivite olarak kabul ettiğimiz kudret sürekli bir şekilde beyinde bulunmaz. Libet ve Haynes'in deneylerine göre fiil meydana geleceği esnada beyinde ortaya çıkar. Eş‘arî ve Mâtürîdîler'in kudretin sürekli bir mahallinin olmadığı görüşünün bu anlamıyla uyumlu olduğu söylenebilir. Ancak fiil ortaya çıktığında kudret Allah tarafından yaratılmaktadır görüşüyle, nerede yaratıldığı konusunda bir yaklaşımlarının olmaması, görüşlerinin tam anlamıyla günümüz bilimiyle karşılaştırılmasına imkân vermemektedir.

\section{Sonuç}

Kelâm ilminde ele alınan birçok konunun fizik, biyoloji, psikoloji, anatomi ve fizyoloji gibi ilimlerle de ilişkili olduğu açık bir vakıadır. Zaten metafizik teoriler inşa eden kelâm âlimlerinin yaşadıkları dönemde bilimsel verilerden çokça faydalandığı bir gerçektir. Kelâmın vesâil alanıyla pozitif ilimlerle etkileşimi sağlaması, bilimsellik vasfını taşıdığını ortaya koymaktadır. Teknolojinin geliştiği bir dönemde metafizik teorilerin pozitif bilimlerle desteklenmesi, kelâmın bilimsellik vasfını koruması açısından önem arz eder.

İnsanlık tarihi boyunca bilimin değişmesi ve gelişmesi bilimsel bilgiler üzeninde inşa edilen metafizik alanda da yeni yaklaşımların geliştirilmesini zorunlu kılmıştır. Ancak bilim ve teknolojideki değişim ve gelişmeler, insan düşüncesini ve zihniyetini birçok yönüyle şekillendirirken kelâm âlimlerinin günümüzde bu reaksiyona tam anlamılla cevap veremediklerini de söyleyebiliriz.

Ortaya çıkışından itibaren bilimsellik vasfı taşıyan kelâmın günümüzde de bu vasfının korunması gerekir. Bunun da yapılabilmesi için kelâma dair teorilerin fizik alanıla ilişkili olan yönlerinin günümüz bilimiyle yeniden inşa edilmeleri gerekir. Bu bağlamda çalışmamızda insanın biyolojik yapısıyla ilintili olan kudretin mahalli konusunu ele aldık. Kelâm âlimleri kudretin mahalli konusunda farklı yaklaşımlar ortaya koymuşlardır. Mu'tezile âlimleri, kudretin mahallinin beden olduğu konusunda ortak bir fikir yürütse de kudretin bedenin bir yerinde mi yoksa uzuvlarda mı olduğu hususunda farklı düşünceler benimsemiş̧ir. Bazı âlimler, kudretin organlarda olduğunu iddia ederken bazıları da kudretin bedenin bir yerinde bulunduğunu iddia etmişlerdir. Bu görüşler, günümüz bilimiyle mukayese edildiğinde kudretin uzuvlarda bulunmadığı görüşünün daha isabetli olduğu görülmüştür. Çünkü elektriksel aktivite olarak kabul ettiğimiz kudretin

${ }_{44}$ Ayrıntılı bilgi için bkz. Benjamin Libet vd., "Time of conscious intention to act in relation to onset of cerebral activity (Readiness-Potential)", Brain 106 (1983), 623-642; John \& Dylan Haynes, "Tracking the Unconscious Generation of Free Decisions Using Uitra-High Field fMRI”, Plosone 6/6 (2011), 1-13; Seyithan Can - Sabahaddin K1lı̧, "Nöroteolojik Açıdan Kesb Nazariyesi (Benjamin Libet Deneyi Çerçevesinde)", Kader 17/2 (2019), 380-397. 
beyinden başlayan ve oradan organları harekete geçiren bir yapı olduğu sonucuna varıldı. Günümüz bilimiyle uyumluluk konusunda Kādî’nin, kudretin bedenin bir yerinden uzuvları harekete geçirdiğine dair benimsediği görüş günümüz bilimiyle uyumluluk arz etmektedir. Mu'tezile âlimlerinin özellikle kudretin bedende sürekli bulunan bir araz olduğu yönündeki iddialarının bilimsel açıdan ortaya konan deneylerle uyuşmadığını tespit ettik. Kudretin uzuvlarda olduğunu söyleyen Mu'tezile âlimlerinin kudretin farklı cins olduğu konusunda iddiaları da söz konusudur. Ancak bu argümanın elektriksel aktivite olarak kabul ettiğimiz kudretle uyuşmadığı, kudretin tek bir cins olduğu ortaya çıkmıştır.

Kudretin bedende sürekli bulunan bir mâna olmadığı hususunda Eşarî ve Mâtürîdî âlimlerinin ortaya koydukları görüşlerin bilimsel verilere daha uygun olduğunu söyleyebiliriz. Onların bu görüşlerine göre kudret Allah tarafından dışardan yaratılmaktadır. Beyindeki fiili meydana getiren elektriksel aktivitenin de fiil daha meydana gelmeden önce ortaya çıkması bu görüşü destekler mahiyettedir. Ancak bu iki ekolün kudretin mahalline dair başka bir yaklaşımına rastlanılmaması, bilimsel açıdan sadece bu kıyaslamanın yapılmasına neden olmuştur. 


\section{Kaynakça}

Abdullah, Muhammed Ramazan. Bâkıllânî ve ârauhu'l-kelâmiyye. Bağdat: Matbaatü'l-Eimme, 1986.

Bağdâdî, Abdülkāhir el-. el-Fark beyne'l-firak. thk. Muhammed Muhyiddîn Abdülhamit. Beyrut: Mektebetü'l-Unsuriyye, 1995.

Bağdâdî, Abdülkāhir el-. Usûlü'd-dîn. İstanbul: Dârülfünun İlâhiyat Fakültesi, 1928.

Benjamin Libet vd. "Time of conscious intention to act in relation to onset of cerebral activity (Readiness-Potential)". Brain 106 (1983), 623-642.

Can, Seyithan. "İnsan Özgürlüğü Bağlaminda Kudretin Devamliliği Sorunu”. İönü University International Journal of Social Sciences (INIJOSS) 7/2 (2018), 1-16.

Can, Seyithan. İnsan Özgürlüğü ve Sorumluluğu Bağlamında Kudret-Fiil İlişkisi. Ankara: Araştırma Yayınları, 2019.

Can, Seyithan. "Modern Anatominin Hareket Kuramı Ekseninde Klasik Kelâmın İnsan Fiilleri Anlayışına Uzlaşımcı Yaklaşım". Kader 18/2 (2020), 570-586.

Can, Seyithan - Kılıç, Sabahaddin. "Nöroteolojik Açıdan Kesb Nazariyesi (Benjamin Libet Deneyi Çerçevesinde)". Kader 17/2 (2019), 380-397.

Cürcânî, Seyyid Şerîf. Şerhu'l-Mevâkıf. çev. Ömer Türker. 3 Cilt. İstanbul: Türkiye Yazma Eserler Kurumu Başkanlığı, 2015.

Cüveynî, Ebü'l- Meâlî el-. Kitâbü'l-Irş̧âd. thk. Muhammed Yusuf Musa - Ali Abdulmunim Abdulhamid. Kahire: Mektebetü'l-Hanci, 1950.

Cüveynî, Ebü'l-Meâlî el-. eş-Şâmil fí usuli'd-dîn. thk. Ali Sami-en Neşşâr. İskenderiye: Müessestu'l-Meârif, 1969.

Duğaym, Semih. Mevsûatu mustalâhâti'l-Eş'arî ve'l- Kãdî Abdülcebbâr. Lübnan: Mektebetu Lubnân, 2002.

Eş'arî, Ebû'l-Hasan el-. el-Lüma' fi'r-red 'alâ ehli'z-zeyg் ve'l-bida'. nşr. Richard J. McCarthy. thk. Ğurabe Hammude. Kahire: Matbaatu'l-Mısriyyetu, 1975.

Eş'arî, Ebü'l-Hasan el-. Makālâtü'l-islâmiyyîn. thk. Helmut Ritter. Beyrut: Dâru'n-Neşr, 2005.

Guyton, Arthur C. - Hall, John E. Tıbbi fizyoloji. çev. Hayrunnisa Çavuşoğlu. İstanbul: Nobel Yayınları, 1996.

İbn Fûrek, Muhammed b.Hasen. Mücerredü makālati'ş-Şeyh Ebi'l Hasan el-Eş'arî. thk. Daniel Gimaret. Beyrut: Dâru'l-Meşrik, 1987.

Jane B. Reece vd. Campbell Biyololoji. çev. Ertunç Gündüz, İsmail Türkan. Ankara: Palme Yayıncllık, 2013.

John \& Dylan Haynes,. "Tracking the Unconscious Generation of Free Decisions Using UitraHigh Field fMRI". Plosone 6/6 (2011), 1-13.

Kādî Abdülcebbâr. el-Muğnî fì ebvâbi't-tevhîd ve'l-adl. thk. Tavil Tevfik - Zeyd Siad. Kahire: elMüessesetü'l-Mısriyyetü'l-Amme, ts.

Kādî Abdülcebbâr. el-Muhtasâr fí usûli'd-dîn. çev. Hulusi Arslan. İstanbul: Endülüs Yayınları, 2017.

Kādî Abdülcebbâr. Kitâbü'l-mecmu' fi'l-muhit bi't-teklif. Beyrut: Mektebetu'l-Kasulikiyyetu, 1962. 
Kādî Abdülcebbâr. Şerhu'l-Usûli'l-hamse. thk. Abdülkerîm Osman. Kâhire: Mektebetü Vehbe, 1996.

Mâtürîdî, Ebû Mansûr. Kitâbu't-Tevhîd. thk. Bekir Topaloğlu - Muhammed Aruçi. Ankara: İSAM Yayınları, 2003.

Nesefî, Ebü'l-Muîn en-. et-Temhîd fî usûli'd-dîn. thk. Kâbil Abdülhey. Kahire: Dâru's-Sekâfeti Li'n-Neşr ve't-Tevzi', 1987.

Nesefî, Ebü'l-Muîn en-. Kitâbu't-Temhîd li kavâidi't-tevhîd. thk. Hasan Ahmed Cibullah. Kahire: Dâru't-tabâati'l-Muhammediyye, 1986.

Nesefî, Ebü'l-Muîn en-. Tebsıratü'l-edille fî usûli'd-dîn. thk. Muhammed Enver Hamid İsa. 2 Cilt. Kahire: el-Mektebetü'l-Ezheriyye li't-Türâs, 2011.

Ocak, Hasan. Tanrı-Insan İlişkisi Bağlamında İnsanın Hürriyeti. İstanbul: Ek Kitap, 2012.

Pezdevî, Ebü'l-Yüsr. Ehl-i Sünnet Akaidi. çev. Şerafettin Gölcük. İstanbul: Kayıhan Yayınları, 2015.

Süt, Abdunnasır. Mu'tezile ve Ahlak-Kadı Abdulcebbar Örneği. İstanbul: İz Yayıncılık, 2016.

Şehristânî, Muhammed b. Abdilkerîm bin Ahmed eş-. el-Milel ve'n-nihâl. thk. Emir Ali Menha. Lübnan: Dârü'l-Mârife, 1993.

Tritton, A.S. İslâm kelâmı. çev. Mehmet Dağ. Ankara: Anakara Üniversitesi Basımevi, 1993.

Türker, Ömer. Ahlak. İstanbul: Ketebe Yayınları, 2019.

Yeprem, M. Saim. Matüridi'nin Akide Risalesi ve Şerhi. İstanbul: Marmara Üniversitesi İlahiyat Fakültesi Vakfı Yayınları, 2000. 